\title{
Effect of the Expanded Senior Citizens Act of 2010 (Republic Act 9994) on Drug Accessibility among the Elderly
}

\author{
Roderick L. Salenga, ${ }^{1}$ Monet M. Loquias, ${ }^{1}$ and Jesus N. Sarol ${ }^{2}$ \\ ${ }^{1}$ Department of Pharmacy, College of Pharmacy, University of the Philippines Manila \\ ${ }^{2}$ National Teachers Training Center for the Health Professions, University of the Philippines Manila
}

\begin{abstract}
Objective. This study aims to determine the effect of the Expanded Senior Citizens Act of 2010 on drug accessibility among elderly.
\end{abstract}

Methods. Descriptive, cross-sectional design involving 775 senior citizens from Manila, Pampanga, lloilo, Bacolod, Cagayan De Oro and lligan.

Results. Thirty-eight percent (38\%) of senior citizens were not aware of the law, but $90 \%$ knew about the $20 \%$ discount and $54 \%$ knew about the $12 \%$ VAT exemption. Half (50\%) of them ask for $20 \%$ discount all the time when they buy their medicines. Only half are given full discount every time they ask for it, and $32 \%$ are given the VAT exemption. As a result, less than half $(48 \%)$ are able to buy all their medicines.

Conclusion. Privileges are not fully enjoyed by senior citizens either due to lack of awareness or noncompliance of drug outlets to the provisions of the Law.

Key Words: senior citizens' welfare, Expanded Senior Citizens Act of 2010, health services accessibility

\section{Introduction}

As of 2010, the Philippines had 6.3 million people aged 60 years and older who accounted for $6.8 \%$ of the country's total population. It is estimated that in the year 2020, this will rise to $10.2 \%$. Elderly persons, as compared to younger individuals, are more likely to have health shocks, costintensive chronic illnesses, and higher probability of living with severe functional limitations. This situation is aggravated by the fact that they, too, are frequently

Portions of the paper were presented at the 17th National Institutes of Health Anniversary, February 26-27, 2015, Bayanihan Center, Unilab, Pasig City; at the 1st DOH Public Health Convention on the Health and Wellness of Senior Citizens, Manila; and at the 2015 Philippine Pharmacists Association National Convention, April 22-26, 2015, SMX Convention Center, Bacolod City.

Corresponding author: Roderick L. Salenga, MPH

Department of Pharmacy

College of Pharmacy

University of the Philippines Manila

Taft Avenue cor. Pedro Gil St., Ermita, Manila 1000 Philippines

Telephone: +6325266115

Email: ericsalenga@gmail.com economically vulnerable and at higher risk of poverty, as disposable income decreases with age. ${ }^{1}$ Given that medicine prices in the Philippines are considered too high compared to neighboring Southeast Asian countries ${ }^{2}$ and that the rapid growth of this elderly segment is expected to continue in high rate, it is very important to develop programs and services that can address their needs for medicines and other health commodities.

In 2010, Republic Act 9994, also known as "The Expanded Senior Citizens Act of 2010," was signed into law. It was in this law that Section 4 of Republic Act No. 7432, as amended by Republic Act No. 9257, otherwise known as the "Expanded Senior Citizens Act of 2003," was further amended. Senior citizens are now entitled to the grant of twenty percent $(20 \%)$ discount and exemption from the value-added tax (VAT), if applicable, on the sale of medicines.

Over the years, much about how demographic ageing impacts on public expenditure have been studied while little effort has been given to understand the economic consequences of demographic changes for individuals, households and communities, most especially the elderly. With ageing, substantial increases in health care spending are anticipated. In 1994, it was estimated that $18.7 \%$ of all health expenditures was attributed to the elderly even though they constituted only about $5.5 \%$ of the population ${ }^{3}$. In 2004, health expenditure of the elderly was projected to increase to $23.5 \%$ in 2010 and $29.5 \%$ in 2020 . Of this total health expenditure, drugs comprise 18 to $21 \%{ }^{4}$

The general objective of the study is to determine the impact of the Expanded Senior Citizens Act of 2010 on drug accessibility among the elderly. Specifically, it aims to: a) determine the effects of the Expanded Senior Citizens Act among the elderly to their economic ability to purchase prescribed medicines, adherence to prescribed therapeutic regimens, and utilization of privileges related to purchase of medicines; and, b) describe their level of satisfaction with the provisions of the law and its implementation.

\section{Materials and Methods}

The study involved a descriptive, cross-sectional design using survey as the data collection method. The sample size for the elderly respondents was computed using the formula 
for estimation of proportions, with a 95\% confidence level, assuming $50 \%$ availment of discounts and maximum tolerable error of $4 \%$. The total sample size computed was 600 .

The study sites were Manila and Pampanga in Luzon, Iloilo and Bacolod City in Visayas, and Cagayan De Oro City and Iligan City in Mindanao. These were purposively selected as critical cases which will permit maximum application of information to other parts of the country. Given that these areas are relatively developed, the limitations in the implementation of the Law seen in these study sites may most likely be true or worse in other places. For each province/city, two municipalities/barangays were stratified randomly selected using income class (i.e. Class 1-2 and Class 3-5) as stratification variable. A structured questionnaire was used during survey. All participants were asked for an informed consent.

\section{Results and Discussion}

The study involved a total of 775 senior citizens. Majority were female, married, with elementary education, Catholic and live with their children (Table 1). On the average, there were about five (5) people in the household. Majority were self-employed earning an average of about $\mathrm{PhP} 4,800$ per month and usually owned the house where they live. Self-employment was especially higher in the Visayas and Mindanao provinces. The senior citizens in the Luzon provinces received higher incomes or retirement benefits or children's support as compared to those from the Visayas and Mindanao provinces.

More than $70 \%$ of the respondents indicated that they are currently experiencing medical problems. The top three medical conditions mentioned were hypertension $(44.3 \%)$, diabetes (18.3\%) and arthritis (16.6\%). About 65\% claimed that they consulted a physician regarding their medical conditions. Seventy percent $(70 \%)$ of the respondents admitted taking medications for their health problems although only $79 \%$ mentioned that these medicines were actually prescribed by their physicians. When asked if they are able to purchase all prescribed medicines, only $74 \%$ responded affirmatively. The primary reason cited for nonpurchase was financial $(85.4 \%)$ in nature. It should be noted that more than $50 \%$ of the senior citizen respondents relied on money/support provided by their children to finance both their basic needs and medications. The support provided was highly variable across provinces. In Mindanao, where the average support provided was observed least which amounted to PhP2,600, only 36\% said they were able to buy all their medicines.

Compliance to prescribed medications was only about $77 \%$. The most common reason for non-compliance was the inability to buy medicines (64.4\%). Others also mentioned taking medicines depending only on the severity of the symptoms $(11.5 \%)$ while still others cited forgetfulness $(10.3 \%)$ and inability to consult physicians (10.3\%).
Fifty-three percent (53\%) of the senior citizen respondents revealed that they use their own money while $44 \%$ said their children pay for their medical expenses. Only $8 \%$ stated PhilHealth as source of health care financing while $13 \%$ mentioned other sources like government assistance, money from relatives and pension. Forty-three percent (43\%) admitted being members of PhilHealth or other health insurance but surprisingly $24 \%$ stated they have never availed of its services whenever they get sick or hospitalized.

Thirty-eight percent (38\%) of the senior citizen respondents claimed that they are not aware of the Expanded Senior Citizens Act of 2010. However, when asked about their awareness of specific provisions like $20 \%$ discount on medicines, $90 \%$ admitted knowledge of the provision. Only 54\% however knew that provisions of the policy also included exemption to the $12 \%$ VAT. Between sexes and among the different civil status, the awareness of the policy or its provisions was not significantly different. This was however observed to be consistently lower among respondents with elementary education and no schooling as well as respondents from Pampanga. In contrast, awareness of the policy and its provisions were consistently higher in the Visayas provinces, Iloilo and Negros Occidental.

In terms of utilization of these benefits, only $50 \%$ asked for the $20 \%$ discount all the time. In instances that the discount is asked, only $50 \%$ were given full $20 \%$ discount by the drug outlets. Among the respondents, only $32 \%$ remembered being given the $12 \%$ VAT exemption by the drug outlets. The more common documents required by drugstores included senior citizen's ID, booklet and prescription. Others would require authorization (when the ID bearer is not the one purchasing the medicines), cedula or community tax certificate and doctor's license number.

Availment and actual provision of the $20 \%$ discount from the drugstores were consistently lower in the Mindanao provinces, Lanao del Norte and Misamis Oriental and Luzon province, Pampanga (Table 2). Across provinces, provision of the $12 \%$ VAT exemption all the time was less than $50 \%$. In Pampanga, this was as low as $12.5 \%$.

It is also interesting to note that awareness of the policy and its provisions seem to play a significant role in the availment and actual provision of the discount and exemption. There was a significantly higher proportion of respondents who were aware of the provisions that were given the $20 \%$ discount all the time $(53.3 \%)$ and the $12 \%$ VAT exemption (49.3\%). Similarly, those respondents with elementary education or no schooling revealed lower proportions in terms of being given the discount and tax exemption all the time.

Despite all the mentioned provisions of the Expanded Senior Citizen's Act, less than 50\% indicated that they were able to buy all their medications. The proportion was even lower in the Mindanao provinces where only 36\% admitted being able to buy all needed medications because of the 
Drug Accessibility among the Elderly

Table 1. Socio-demographic profile of senior citizen respondents

\begin{tabular}{|c|c|c|c|c|c|c|c|c|c|}
\hline \multirow{2}{*}{ Variables } & \multirow{2}{*}{ Attributes } & \multicolumn{2}{|c|}{ Luzon } & \multicolumn{2}{|c|}{ Visayas } & \multicolumn{2}{|c|}{ Mindanao } & \multicolumn{2}{|c|}{ Total } \\
\hline & & NO. & $\%$ & NO. & $\%$ & NO. & $\%$ & NO. & $\%$ \\
\hline \multirow{3}{*}{ Sex } & No. of respondents & 258 & $33.3 \%$ & 259 & $33.4 \%$ & 258 & $33.3 \%$ & & \\
\hline & 1-Female & 163 & $63.2 \%$ & 160 & $61.8 \%$ & 173 & $67.1 \%$ & 496 & $64.0 \%$ \\
\hline & 2-Male & 95 & $36.8 \%$ & 99 & $38.2 \%$ & 85 & $33.0 \%$ & 279 & $36.0 \%$ \\
\hline Age & ACTUAL AGE: & MEAN & 68.3 & MEAN & 69.3 & MEAN & 68.8 & MEAN & 68.8 \\
\hline \multirow{8}{*}{ Civil status } & 1-Single & 14 & $5.4 \%$ & 25 & $9.7 \%$ & 7 & $2.7 \%$ & 46 & $5.9 \%$ \\
\hline & 2-Married & 132 & $51.2 \%$ & 144 & $55.6 \%$ & 132 & $51.2 \%$ & 408 & $52.7 \%$ \\
\hline & 3-Separated & 12 & $4.7 \%$ & 10 & $3.9 \%$ & 12 & $4.7 \%$ & 34 & $4.4 \%$ \\
\hline & 4-Widow/er & 100 & $38.8 \%$ & 80 & $30.9 \%$ & 107 & $41.5 \%$ & 287 & $37.0 \%$ \\
\hline & 1-No schooling & 6 & $2.3 \%$ & 3 & $1.2 \%$ & 12 & $4.7 \%$ & 21 & $2.7 \%$ \\
\hline & 2-Elementary level & 46 & $17.8 \%$ & 56 & $21.6 \%$ & 57 & $22.1 \%$ & 159 & $20.5 \%$ \\
\hline & 3-Elementary graduate & 60 & $23.3 \%$ & 40 & $15.4 \%$ & 40 & $15.5 \%$ & 140 & $18.1 \%$ \\
\hline & 4-High school level & 27 & $10.5 \%$ & 54 & $20.9 \%$ & 36 & $14.0 \%$ & 117 & $15.1 \%$ \\
\hline \multirow{7}{*}{ Education } & 5-High school graduate & 44 & $17.1 \%$ & 39 & $15.1 \%$ & 54 & $20.9 \%$ & 137 & $17.7 \%$ \\
\hline & 6-Vocational & 6 & $2.3 \%$ & 8 & $3.1 \%$ & 6 & $2.3 \%$ & 20 & $2.6 \%$ \\
\hline & 7-College level & 34 & $13.2 \%$ & 19 & $7.3 \%$ & 26 & $10.1 \%$ & 79 & $10.2 \%$ \\
\hline & 8-College graduate & 33 & $12.8 \%$ & 37 & $14.3 \%$ & 25 & $9.7 \%$ & 95 & $12.3 \%$ \\
\hline & 9-Post graduate & 2 & $0.8 \%$ & 3 & $1.2 \%$ & 2 & $0.8 \%$ & 7 & $0.9 \%$ \\
\hline & 1-Roman Catholic & 230 & $89.2 \%$ & 227 & $87.6 \%$ & 225 & $87.2 \%$ & 682 & $88.0 \%$ \\
\hline & 2-Protestant & 1 & $0.4 \%$ & 5 & $1.9 \%$ & 1 & $0.4 \%$ & 7 & $0.9 \%$ \\
\hline \multirow{6}{*}{ Religion } & 3-Christian & 9 & $3.5 \%$ & 7 & $2.7 \%$ & 6 & $2.3 \%$ & 22 & $2.8 \%$ \\
\hline & 4-Iglesia ni Cristo & 6 & $2.3 \%$ & 4 & $1.5 \%$ & 8 & $3.1 \%$ & 18 & $2.3 \%$ \\
\hline & 5-Islam & 2 & $0.8 \%$ & 3 & $1.2 \%$ & & & 5 & $0.7 \%$ \\
\hline & 6-Others & 10 & $0.04 \%$ & 13 & $5.0 \%$ & 18 & $7.0 \%$ & 41 & $5.3 \%$ \\
\hline & 1-None, living alone & 17 & $6.6 \%$ & 28 & $10.8 \%$ & 13 & $5.0 \%$ & 58 & $7.5 \%$ \\
\hline & 2-Spouse & 123 & $47.7 \%$ & 131 & $50.6 \%$ & 144 & $55.8 \%$ & 398 & $51.35 \%$ \\
\hline \multirow{5}{*}{ Living companion } & 3-Children & 180 & $69.8 \%$ & 156 & $60.2 \%$ & 172 & $66.7 \%$ & 508 & $65.6 \%$ \\
\hline & 4-Caregiver & 3 & $1.2 \%$ & 3 & $1.2 \%$ & 9 & $3.5 \%$ & 15 & $1.9 \%$ \\
\hline & 5-Other relatives & 170 & $65.9 \%$ & 114 & $44.0 \%$ & 67 & $26.0 \%$ & 351 & $45.3 \%$ \\
\hline & 1- House & 167 & $64.7 \%$ & 225 & $86.9 \%$ & 184 & $71.3 \%$ & 576 & $74.3 \%$ \\
\hline & 2- Land & 124 & $48.1 \%$ & 136 & $52.5 \%$ & 124 & $48.1 \%$ & 384 & $49.6 \%$ \\
\hline \multirow{4}{*}{$\begin{array}{l}\text { Ownership of } \\
\text { properties }\end{array}$} & 3-Farmland & 30 & $11.6 \%$ & 20 & $7.7 \%$ & 8 & $3.1 \%$ & 58 & $7.5 \%$ \\
\hline & 4-Vehicle & 42 & $16.3 \%$ & 14 & $5.4 \%$ & 15 & $5.8 \%$ & 71 & $9.2 \%$ \\
\hline & 5-Jewelries & 35 & $13.6 \%$ & 9 & $3.5 \%$ & 10 & $3.9 \%$ & 54 & $7.0 \%$ \\
\hline & 6-Others & 18 & $7.0 \%$ & 5 & $1.9 \%$ & 11 & $4.3 \%$ & 34 & $4.4 \%$ \\
\hline \multirow[t]{8}{*}{ People in Household } & & MEAN & 5.3 & MEAN & 4.2 & MEAN & 4.8 & MEAN & 4.8 \\
\hline & & & AMOUNT & & AMOUNT & & AMOUNT & & AMOUNT \\
\hline & & $\%$ & MEAN & $\%$ & MEAN & $\%$ & MEAN & $\%$ & MEAN \\
\hline & & $\%$ & MEDIAN & $\%$ & MEDIAN & $\%$ & MEDIAN & $\%$ & MEDIAN \\
\hline & & & MODE & & MODE & & MODE & & MODE \\
\hline & 1-Self- employed, & & $5,585.92$ & & 4556.67 & & $4,009.09$ & & $4,832.05$ \\
\hline & type and net income & $39.5 \%$ & $4,500.00$ & $54.1 \%$ & $2,500.00$ & $44.6 \%$ & $2,000.00$ & $46.1 \%$ & $3,000.00$ \\
\hline & per month & & $5,000.00$ & & $1,000.00$ & & $2,000.00$ & & $1,000.00$ \\
\hline \multirow{9}{*}{$\begin{array}{c}\text { Sources of } \\
\text { income/finances }\end{array}$} & & & 5743.53 & & 4464.29 & & 7042.38 & & 6227.75 \\
\hline & 2-Retirement benefits, & $25.6 \%$ & 3000 & $22.8 \%$ & 2750 & $29.5 \%$ & 4000 & $25.9 \%$ & 3500 \\
\hline & & & 3000 & & 7000 & & 4000 & & 5000 \\
\hline & & & 7299.35 & & 6625 & & 2651.50 & & 5251.28 \\
\hline & 3-Children's support, & $50.8 \%$ & 5000 & $30.9 \%$ & 6150 & $35.7 \%$ & 1000 & $39.1 \%$ & 2900 \\
\hline & & & 5000 & & 10000 & & 500 & & 2000 \\
\hline & & & 6090.91 & & 12000 & & & & 6583.33 \\
\hline & 4-Others & $12.4 \%$ & 4000 & $3.1 \%$ & 12000 & $4.3 \%$ & NA & $6.6 \%$ & 5000 \\
\hline & & & 10000 & & 12000 & & & & 10000 \\
\hline
\end{tabular}

discount and exemption provided. This was only $33.6 \%$ in Pampanga and a low 26.9\% in Lanao del Norte. Being able to buy medicines as a result of the discounts was highest in Iloilo at $65.6 \%$. Those with elementary education or less also posted lower proportion of those who were able to buy all medications needed (Table 2). On the other hand, adherence to medications which may or may not be directly resulting from the provisions of the policy was only at $54 \%$. Adherence was observed highest in the NCR at $66.9 \%$ and least in Pampanga at $41.4 \%$. Adherence was likewise observed lower among respondents with elementary education or no schooling. Still, inability to buy medicines was the most frequently cited reason and this can still be correlated with finances and buying power of the senior citizens. Adherence is a complex phenomenon and cannot be explained by a single factor. Hence while affordability is a contributing factor, it is not the only reason that can explain adherence or non-adherence. Other reasons should be explored so specific strategies may be created to improve adherence. It is important to explain the 
Table 2. Awareness, availment and actual provisions of benefits in the Expanded Senior Citizens Act of 2010 vis-à-vis ability to purchase medicines and adherence

\begin{tabular}{|c|c|c|c|c|c|c|c|c|}
\hline & $\begin{array}{c}\text { Awareness } \\
\text { of the SC } \\
\text { ACT }^{*}\end{array}$ & $\begin{array}{l}\text { Awareness } \\
\text { of the } 20 \% \\
\text { discount* }\end{array}$ & $\begin{array}{c}\text { Awareness } \\
\text { of the } 12 \% \\
\text { VAT } \\
\text { exemption* }\end{array}$ & $\begin{array}{l}\text { Availment } \\
\text { of the } 20 \% \\
\text { discount }\end{array}$ & $\begin{array}{c}\text { Actual } \\
\text { provision of } \\
20 \% \\
\text { discount }^{* *}\end{array}$ & $\begin{array}{c}\text { Actual } \\
\text { exemption } \\
\text { from the } \\
12 \% \text { VAT } * *\end{array}$ & $\begin{array}{c}\text { Ability to } \\
\text { buy } \\
\text { medicines } \\
* *\end{array}$ & $\begin{array}{c}\text { Adherence } \\
\text { to medicines } \\
* *\end{array}$ \\
\hline \multicolumn{9}{|l|}{ Province } \\
\hline Pampanga & $32(25.0 \%)$ & $106(82.8 \%)$ & $32(25.0 \%)$ & $51(39.8 \%)$ & $45(35.2 \%)$ & $16(12.5 \%)$ & $43(33.6 \%)$ & $53(41.4 \%)$ \\
\hline NCR & $54(41.5 \%)$ & $126(96.9 \%)$ & $71(54.6 \%)$ & $97(74.8 \%)$ & $95(73.1 \%)$ & $52(40.0 \%)$ & $72(55.4 \%)$ & $87(66.9 \%)$ \\
\hline Negros Occidental & $102(79.7 \%)$ & $119(93.0 \%)$ & $65(50.8 \%)$ & $65(50.8 \%)$ & $59(46.1 \%)$ & $39(30.5 \%)$ & $86(65.6 \%)$ & $58(45.3 \%)$ \\
\hline Iloilo & $113(86.3 \%)$ & $122(93.1 \%)$ & $75(57.3 \%)$ & $81(61.8 \%)$ & $80(61.1 \%)$ & $52(39.7 \%)$ & $86(65.6 \%)$ & $83(63.4 \%)$ \\
\hline Lanao del Norte & $84(64.6 \%)$ & $109(83.8 \%)$ & $89(68.5 \%)$ & $49(37.7 \%)$ & $53(40.8 \%)$ & $50(38.5 \%)$ & $35(26.9 \%)$ & $67(51.5 \%)$ \\
\hline Misamis Oriental & $92(71.9 \%)$ & $109(85.2 \%)$ & $84(66.1 \%)$ & $44(34.4 \%)$ & $50(39.1 \%)$ & $33(25.8 \%)$ & $54(42.2 \%)$ & $52(40.6 \%)$ \\
\hline \multicolumn{9}{|l|}{ Sex } \\
\hline Male & $164(58.8 \%)$ & $254(91.0 \%)$ & $154(55.4 \%)$ & $145(52.0 \%)$ & $133(47.7 \%)$ & $85(30.5 \%)$ & $116(41.6 \%)$ & $135(48.4 \%)$ \\
\hline Female & $313(63.1 \%)$ & $437(88.1 \%)$ & $262(52.8 \%)$ & $242(48.8 \%)$ & $249(50.2 \%)$ & $157(31.7 \%)$ & $229(46.2 \%)$ & $265(53.4 \%)$ \\
\hline \multicolumn{9}{|l|}{ Civil Status } \\
\hline Single & $32(69.6 \%)$ & $44(95.7 \%)$ & $29(63.0 \%)$ & $26(56.5 \%)$ & $24(52.2 \%)$ & $19(41.3 \%)$ & $26(56.5 \%)$ & $28(60.9 \%)$ \\
\hline Married & $245(60.0 \%)$ & $372(91.2 \%)$ & $219(53.8 \%)$ & $212(52.0 \%)$ & $203(49.8 \%)$ & $128(31.4 \%)$ & $178(43.6 \%)$ & $212(52.0 \%)$ \\
\hline Separated & $21(61.8 \%)$ & $32(94.1 \%)$ & $22(64.7 \%)$ & $12(35.3 \%)$ & $14(41.2 \%)$ & $12(35.3 \%)$ & $11(32.4 \%)$ & $16(47.1 \%)$ \\
\hline Widower & $179(62.4 \%)$ & $243(84.7 \%)$ & $146(50.9 \%)$ & $137(47.7 \%)$ & $141(49.1 \%)$ & $83(28.9 \%)$ & $130(45.3 \%)$ & $144(50.2 \%)$ \\
\hline \multicolumn{9}{|l|}{ Education } \\
\hline No schooling & $12(57.1 \%)$ & 15 (71.4\%) & $10(47.6 \%)$ & $9(42.9)$ & $7(33.3 \%)$ & $7(33.3 \%)$ & $5(23.8 \%)$ & $2(9.5 \%)$ \\
\hline Elementary level & $90(56.6 \%)$ & $127(79.9 \%)$ & $68(42.8 \%)$ & $51(32.1 \%)$ & $53(33.3 \%)$ & $36(22.6 \%)$ & $54(34.0 \%)$ & $8(5.0 \%)$ \\
\hline Elementary graduate & $73(52.1 \%)$ & $125(89.3 \%)$ & $62(44.3 \%)$ & $65(46.4 \%)$ & $65(46.4 \%)$ & $29(20.7 \%)$ & $55(39.3 \%)$ & $10(7.1 \%)$ \\
\hline High school level & $72(61.5 \%)$ & $107(91.5 \%)$ & $64(54.7 \%)$ & $60(51.3 \%)$ & $59(50.4 \%)$ & $36(30.8 \%)$ & $52(44.4 \%)$ & $6(5.1 \%)$ \\
\hline High school graduate & $81(59.1 \%)$ & $126(92.0 \%)$ & $80(58.4 \%)$ & $70(51.1 \%)$ & $68(49.6 \%)$ & $46(33.6 \%)$ & $54(39.4 \%)$ & $6(4.4 \%)$ \\
\hline Vocational & $19(95.0 \%)$ & $20(100.0 \%)$ & $16(80.0 \%)$ & $12(60 \%)$ & $14(70.0 \%)$ & $10(50.0 \%)$ & $12(60.0 \%)$ & $0(0.0 \%)$ \\
\hline College level & $49(62.0 \%)$ & $75(94.9 \%)$ & $39(50.0 \%)$ & $51(64.6 \%)$ & $50(63.3 \%)$ & $34(43.0 \%)$ & $44(55.7 \%)$ & $4(5.1 \%)$ \\
\hline College graduate & $74(77.9 \%)$ & $89(93.7 \%)$ & $72(75.8 \%)$ & $66(69.5 \%)$ & $63(66.3 \%)$ & $42(44.2 \%)$ & $64(67.4 \%)$ & $1(1.1 \%)$ \\
\hline Post graduate & $7(100.0 \%)$ & $7(100.0 \%)$ & $5(71.4 \%)$ & $3(42.9 \%)$ & $3(42.9 \%)$ & $2(28.6 \%)$ & $5(71.4 \%)$ & $1(14.3 \%)$ \\
\hline
\end{tabular}

*Frequencies (\%) of respondents who answered "Yes"

**Frequencies (\%) of respondents who answered "All the time"

Table 3. Satisfaction level of senior citizens

\begin{tabular}{|c|c|c|c|c|c|c|c|c|c|}
\hline & & \multicolumn{2}{|c|}{ Luzon } & \multicolumn{2}{|c|}{ Visayas } & \multicolumn{2}{|c|}{ Mindanao } & \multicolumn{2}{|c|}{ Total } \\
\hline & 1-Very unsatisfactory & 11 & $4.3 \%$ & 19 & $7.3 \%$ & 18 & $7.0 \%$ & 48 & $6.2 \%$ \\
\hline \multirow{5}{*}{$\begin{array}{l}\text { Are you satisfied with the implementation of the } \\
\text { Expanded Senior Citizens Act of } 2010 \text { in terms of } \\
\text { the giving of } 20 \% \text { discount on your medicines? }\end{array}$} & 2-Unsatisfactory & 19 & $7.5 \%$ & 10 & $3.9 \%$ & 5 & $1.9 \%$ & 34 & $4.4 \%$ \\
\hline & 3-Average & 72 & $28.2 \%$ & 42 & $16.2 \%$ & 45 & $17.4 \%$ & 159 & $20.6 \%$ \\
\hline & 4-Satisfactory & 68 & $26.7 \%$ & 64 & $24.7 \%$ & 46 & $17.8 \%$ & 178 & $23.1 \%$ \\
\hline & 5-Very satisfactory & 85 & $33.3 \%$ & 124 & $47.9 \%$ & 144 & $55.8 \%$ & 353 & $45.7 \%$ \\
\hline & 1 -Very unsatisfactory & 66 & $25.9 \%$ & 52 & $20.1 \%$ & 42 & $16.3 \%$ & 160 & $20.7 \%$ \\
\hline \multirow{4}{*}{$\begin{array}{l}\text { Are you satisfied with the implementation of the } \\
\text { Expanded Senior Citizens Act of } 2010 \text { in terms of } \\
\text { the } 12 \% \text { VAT exemption of your medicines? }\end{array}$} & 2-Unsatisfactory & 31 & $12.2 \%$ & 12 & $4.6 \%$ & 34 & $13.2 \%$ & 77 & $10.0 \%$ \\
\hline & 3-Average & 60 & $23.5 \%$ & 47 & $18.2 \%$ & 53 & $20.5 \%$ & 160 & $20.7 \%$ \\
\hline & 4-Satisfactory & 40 & $15.7 \%$ & 54 & $20.9 \%$ & 38 & $14.7 \%$ & 132 & $17.1 \%$ \\
\hline & 5-Very satisfactory & 58 & $22.8 \%$ & 94 & $36.3 \%$ & 91 & $35.3 \%$ & 243 & $31.5 \%$ \\
\hline \multirow{4}{*}{$\begin{array}{l}\text { As a whole, can you say that the Expanded Senior } \\
\text { Citizens Act of } 2010 \text { is addressing the issue of } \\
\text { accessibility of medicines for the elderly? }\end{array}$} & $1-\mathrm{No}$ & 32 & $12.5 \%$ & 31 & $12.0 \%$ & 14 & $5.4 \%$ & 77 & $10.0 \%$ \\
\hline & 2-Yes & 184 & $71.6 \%$ & 191 & $73.8 \%$ & 195 & $75.6 \%$ & 570 & $73.6 \%$ \\
\hline & 3-Not sure & 41 & $16.0 \%$ & 37 & $14.3 \%$ & 49 & $19.0 \%$ & 127 & $16.4 \%$ \\
\hline & Increase discount & & & & & & & 107 & $21.8 \%$ \\
\hline \multirow[t]{10}{*}{ Suggestions for improvement } & Increase benefits & & & & & & & 50 & $10.2 \%$ \\
\hline & Give/increase pension & & & & & & & 62 & $12.6 \%$ \\
\hline & Strict implementation & & & & & & & 110 & $22.4 \%$ \\
\hline & Give allowance to elde & & & & & & & 45 & $9.2 \%$ \\
\hline & Expand discount cover & & & & & & & 15 & $3.1 \%$ \\
\hline & Decrease requirements & & & & & & & 45 & $9.2 \%$ \\
\hline & Increase knowledge/ in & orma & for seni & tizens & & & & 11 & $2.2 \%$ \\
\hline & Faster processing of SC & applic & & & & & & 5 & $1.0 \%$ \\
\hline & Give free medicines & & & & & & & 32 & $6.5 \%$ \\
\hline & Lower drug prices & & & & & & & 5 & $1.0 \%$ \\
\hline
\end{tabular}

importance of adherence among patients taking their medications. It should also be pointed out that in some study sites, the ability to purchase all medicines was lower than the self-reported adherence to medications of respondents. This can be due to the fact that many of the senior citizens depend on the support of other members of the family. It is possible that while they themselves cannot buy the medicines, other individuals make them available to them. 
Drug Accessibility among the Elderly

Table 4. Satisfaction level of senior citizens by demographic variables

\begin{tabular}{|c|c|c|c|}
\hline & $\begin{array}{l}\text { Satisfaction with the implementation of } \\
\text { the } 20 \% \text { discount }\end{array}$ & $\begin{array}{c}\text { Satisfaction with the implementation of } \\
\text { the } 12 \% \text { VAT exemption* }\end{array}$ & $\begin{array}{l}\text { Address issue of } \\
\text { accessibility** }\end{array}$ \\
\hline \multicolumn{4}{|l|}{ Province } \\
\hline Pampanga & $64(51.2 \%)$ & $38(30.4 \%)$ & $78(61.4 \%)$ \\
\hline NCR & $89(68.4 \%)$ & $60(46.2 \%)$ & $106(81.5 \%)$ \\
\hline Negros Occidental & $81(63.3 \%)$ & $67(52.4 \%)$ & $90(70.3 \%)$ \\
\hline Iloilo & $107(81.7 \%)$ & $81(61.8 \%)$ & $101(77.1 \%)$ \\
\hline Lanao del Norte & $101(77.7 \%)$ & $63(48.5 \%)$ & $103(79.2 \%)$ \\
\hline Misamis Oriental & $89(69.5 \%)$ & $66(51.6 \%)$ & $92(71.9 \%)$ \\
\hline \multicolumn{4}{|l|}{ Sex } \\
\hline Male & $187(67.3 \%)$ & $131(47.1 \%)$ & $196(70.3 \%)$ \\
\hline Female & $344(69.7 \%)$ & $244(49.4 \%)$ & $374(75.6 \%)$ \\
\hline \multicolumn{4}{|l|}{ Civil Status } \\
\hline Single & $32(69.6 \%)$ & $26(56.5 \%)$ & $37(80.4 \%)$ \\
\hline Married & $277(68.2 \%)$ & $198(48.7 \%)$ & $293(72.0 \%)$ \\
\hline Separated & $24(70.6 \%)$ & $18(52.9 \%)$ & $28(82.4 \%)$ \\
\hline Widower & $198(69.3 \%)$ & $133(46.5 \%)$ & $212(73.9 \%)$ \\
\hline \multicolumn{4}{|l|}{ Education } \\
\hline No schooling & $15(71.4 \%)$ & $8(38.0 \%)$ & $18(85.7 \%)$ \\
\hline Elementary level & $100(63.3 \%)$ & $69(43.7 \%)$ & $104(65.4 \%)$ \\
\hline Elementary graduate & $86(61.8 \%)$ & $61(43.8 \%)$ & $90(64.7 \%)$ \\
\hline High school level & $86(74.2 \%)$ & $59(50.9 \%)$ & $90(76.9 \%)$ \\
\hline High school graduate & $97(70.8 \%)$ & $72(52.5 \%)$ & $108(78.8 \%)$ \\
\hline Vocational & $13(65.0 \%)$ & $10(50.0 \%)$ & $14(70.0 \%)$ \\
\hline College level & $56(70.9 \%)$ & $34(43.1 \%)$ & $66(83.5 \%)$ \\
\hline College graduate & $72(75.8 \%)$ & $56(58.9 \%)$ & $74(77.9 \%)$ \\
\hline Post graduate & $6(85.7 \%)$ & $6(85.7 \%)$ & $6(85.7 \%)$ \\
\hline
\end{tabular}

*Frequencies (\%) of respondents who answered "Satisfactory" and "Very Satisfactory"

** Frequencies (\%) of respondents who answered "Yes"

More than $90 \%$ of the respondents rated the implementation of the Expanded Senior Citizens Act as average to very satisfactory in terms of the $20 \%$ discount provision but only about $69 \%$ in terms of the $12 \%$ VAT exemption provision (Table 3).

Across provinces, majority answered satisfactory to very satisfactory for the implementation of the $20 \%$ discount provision. Lanao del Norte and Misamis Oriental showed higher proportion of respondents who rated the Expanded Senior Citizens Act favorably while this was least in Pampanga (Table 4). Across educational levels, respondents were likewise more satisfied with the implementation of the $20 \%$ discount than the $12 \%$ VAT exemption.

Seventy-four percent $(74 \%)$ felt that the policy is able to address the issue of accessibility of medicines among the elderly, despite the fact that many cannot still buy all their medications. This sentiment was observed to be highest in the NCR at $81.5 \%$ and least in Pampanga at $61.4 \%$. Across educational levels, majority of the respondents $(64 \%$ to $86 \%)$ likewise agreed that the Expanded Senior Citizens Act addresses the issue of accessibility among the elderly.

Majority suggested increasing discounts and strict implementation as recommendations in order to improve policy (Table 3).

This study was able to include a limited number of areas in the country, which may not necessarily be able to present adequately the general situation in the Philippines.
The number of pharmacies is also not large enough to be able to exhaustively list issues and problems related to implementing the provisions of the law.

Several problems were also encountered during the interview with the staff of the pharmacy outlets. Most of the time there was no pharmacist present in the drugstore. Also, the staff of some pharmacy outlets were very hesitant to be interviewed claiming that their supervisors would not allow them. Some did not allow the interview to be recorded. Staff members from some large chain drugstores did not want to be interviewed; some said that they needed permission from their main office and an endorsement letter from the Department of Health was necessary.

\section{Conclusion}

Many elderly respondents are still not fully aware of the Expanded Senior Citizens Act of 2010. Although majority knows that they should enjoy 20\% discount on their medicines, only half of the respondents knew that their medicines purchases should also be exempted from VAT. Given these, half of the senior citizens still do not actively demand for these privileges all the time they are buying their medicines. Probably because of limited knowledge about the law, majority of the elderly rated the implementation as average to very satisfactory. Majority even indicated that the policy is able to address the issue of accessibility of medicines among the elderly. 
While the intention of the law is good, it is important for the government to study the negative impact of the provisions to the pharmacy retail outlets which now serve as the partner of the government in providing the much needed medications at the community level. The glaring information that not all senior citizens receive the mandated discount and tax exemption provide a signal that there is something wrong, either in the law itself or in its implementing rules and regulations. The inability of the drug outlets may mean a gap in terms of who should really carry the cost of discounting and exemption.

The inability of many senior citizens to purchase their medicines in spite of all these privileges also means that wider information dissemination is needed. It is also interesting to determine if the increase in the purchasing power of the elderly sector is in terms of allowing even the poorer senior citizens to avail their medicines, or just allowing the previously financially capable elders to enjoy discounts.

\section{Acknowledgement}

The researchers would like to acknowledge the funding from the Department of Health (DOH), and the technical assistance from the Philippine Council for Health Research and Development (PCHRD) that were critical in the completion of this study.

\section{References}

1. Scheil-Adlung X, Bonan J. Can the European elderly afford the financial burden of health and long-term care? Assessing impacts and policy implications. Geneva: International Labour Organization; 2012. pp. 1-33. ISBN: 978-92-2-126294.

2. Batangan DB, Echavez C, Santiago AA, De la Cruz AC, Santos E. The prices people have to pay for medicines in the Philippines [Online]. 2005 [cited 2013 Jan]. Available from http://www.haiweb.org/medicineprices/ surveys/200502PH/sdocs/survey_report.pdf. pp. 1-34

3. Russo G, Racelis R, Mason A. Baseline estimates of health care expenditures of older persons: Philippines, 1994. East-West Center, Aging Populations: Health Systems and Policy Reform Project; 2003.

4. Mason A, Racelis R, Russo G, Wongkaren T. Technical report on projects and their implications in the Philippines, 1994-2010. East-West Center, Aging populations: Health Systems and Policy Reform; 2004.

5. Aziz MM, Calvo MC, Schneider IJC, Xavier AJ and d'Orsi E. Prevalence and Factors Associated with Access to Medication among the Elderly in a City in Southern Brazil: A Population-based Study. Cad. Saúde Pública 2011; 27(10): 1939-1950.

6. Carlos CC. Concerns of the elderly in the Philippines. Philippine Social Sciences Review. 1999; 56(1-4):1-40.

7. Lerdkulladilok O. "The Management and Development of Social Services for Senior Citizens in the Philippines and Malaysia". Are We Up to the Challenge? Current Crises and the Asian Intellectual Community-The Work of the 2005/2006 API Fellows. Bangkok: The Nippon Foundation, 2008. pp. 54-66.

8. Li X, Guh D, Lacaille D, Esdaile J, Anis AH. The impact of cost sharing of prescription drug expenditures on health care utilization by the elderly: own-and cross-price elasticities. [Abstract] Health Policy. 2007; 82(3):340-7.

9. Spinewine A, Swine C, Dhillon S, et al. Appropriateness of use of medicines in elderly inpatients: qualitative study. BMJ. 2005; 331(7522):935-8.

10. Lee YC, Yang MC, Huang YT, Liu CH, Chen SB. Impacts of cost containment strategies on pharmaceutical expenditures of the national health insurance in Taiwan, 1996-2003. Pharmacoeconomics 2006; 24(9):891-902. 